\title{
Secondary Prevention Measures after Acute Myocardial Infarction: Comparison between Diabetics and Non-Diabetics at a Saudi Teaching Hospital
}

\author{
Daad H. Akbar \\ King Abdulaziz University Hospital, Jeddah, Kingdom of Saudi Arabia
}

\author{
Key Words \\ Secondary prevention - Myocardial \\ infarction - Diabetics - Non-diabetics . \\ Saudi Arabia
}

\begin{abstract}
Objective: To compare between the use of secondary prevention measures after acute myocardial infarction in diabetic and nondiabetic patients who were admitted to the King Abdulaziz University Hospital. Method: All patients admitted with a definitive diagnosis of acute myocardial infarction between January 1995 and December 1999 were studied. Patients' age, sex, body mass index, development of heart failure, peak serum creatinine phosphokinase, duration of hospital stay, use of aspirin, beta-blockers or angiotensin-converting enzyme (ACE) inhibitors on discharge and outcome were reported. Results: A total of 184 patients were studied, $53 \%$ were diabetics and $47 \%$ non-diabetics.
\end{abstract}

\begin{tabular}{ll}
\hline KARGER & (1) 1998 S. Karger AG, Basel \\
Fax +41 61 306 1234 34 1011-7571/00/0093-0181\$17.50/0 \\
$\begin{array}{l}\text { E-Mail karger@karger.ch } \\
\text { www.karger.com }\end{array}$ & $\begin{array}{l}\text { Accessible online at: } \\
\text { www.karger.com/journals/mpp }\end{array}$
\end{tabular}

The mean age for diabetics was 56 years with a male:female ratio of 3.9:1, while for nondiabetics it was 53 years with a male:female ratio of 7.7:1 ( $p=0.05, p=0.09$, respectively). Diabetic patients had a higher incidence of heart failure compared to non-diabetics, 57 versus $43 \%$ ( $p=0.05)$, and had a longer hospital stay, 12 versus 10 days ( $p=0.03$ ). Aspirin was used by $97 \%$ of the diabetics and $94 \%$ of the non-diabetics ( $p=0.4$ ), while betablockers were used by 43 and $44 \%(p=0.9)$ and ACE inhibitors by 67 and $51 \%(p=0.03)$, respectively. Conclusion: There is no difference in the use of aspirin and beta-blockers between diabetic and non-diabetic patients. ACE inhibitors were used more by diabetics. There is underutilization of beta-blockers by diabetics and non-diabetics. Physicians should be encouraged to use beta-blockers as secondary prevention measures after acute myocardial infarction as they have substantial benefits and are of generally low treatment cost.

Copyright $\odot 2001$ S. Karger AG, Basel

$$
\begin{aligned}
& \text { Dr. Daad H. Akbar } \\
& \text { King Abdulaziz University Hospital } \\
& \text { PO Box 18298, Jeddah 21415 (Saudi Arabia) } \\
& \text { Tel. +966 2 6557043/6586516, Fax +966 2 6541626 } \\
& \text { E-Mail daadakb@yahoo.com }
\end{aligned}
$$




\section{Introduction}

It is well known that diabetic patients have a worse outcome after myocardial infarction (MI) than non-diabetic patients $[1,2]$. The effectiveness of beta-blockers as a secondary prevention measure after acute MI was appraised by Yusuf et al. [3]. Several large trials have demonstrated that the long-term administration of beta-blockers to patients after acute MI improves survival [4-6]. Although the percentage of patients receiving betablockers after acute MI has recently increased, physicians still reportedly prescribe betablockers for less than one third of the patients [7] and cardiologists for less than one half [8]. Chowdury et al. [9] have reported that diabetic patients do not receive optimal secondary prevention measure when compared to their non-diabetic counterparts, although the mortality associated with MI is reduced considerably in diabetic patients treated with angiotensin-converting enzyme (ACE) inhibitors and beta-blockers compared to non-diabetic patients treated with the same drugs [10].

The aim of our study is to compare the use of secondary prevention measures in diabetic and non-diabetic patients admitted to the King Abdulaziz University Hospital with a diagnosis of acute MI over a 5-year period.

\section{Method}

King Abdulaziz University Hospital is a 400-bed teaching hospital in Jeddah, Kingdom of Saudi Arabia. The medical charts of patients admitted to the hospital with a definitive diagnosis of acute MI between January 1995 and December 1999 were reviewed. Definitive diagnosis of acute MI was made by the presence of at least two of the following criteria: (1) a history of prolonged chest discomfort, (2) electrocardiographic changes consistent with ischaemia or necrosis, (3) elevated cardiac enzymes [11]. Patients were divided into two groups according to the presence or absence of diabetes mellitus. Diagnosis of diabetes mellitus was made according to the WHO criteria [12]. Patients' age, sex, body mass index (body weight in kilograms divided by height in square metres) as well as the development of heart failure (whether on admission or as a late complication), peak serum creatinine phosphokinase, duration of hospital stay, use of aspirin, beta-blockers, ACE inhibitors on discharge and outcome were recorded. Cardiac enzyme analyses were performed using enzymatic colorimetric method with the normal range being from 0 to 195 IU/1.

\section{Statistical Analysis}

Analyses were performed using the SPSS 7.5 (Statistical Package for Social Science). Mean \pm SD was determined for qualitative data, and frequency was determined for categorical variables. For continuous variables $t$ test was used when comparing two groups. Chi-square was used to analyse group differences for categorical variables. All tests were two-tailed, and a $p$ value of $<0.05$ was considered significant.

\section{Results}

A total of 184 patients were included in the study. Ninety-seven patients (53\%) were diabetics and 87 (47\%) were non-diabetics. The mean age for diabetics was $56.4 \pm 11$ years and $52.6 \pm 14$ years for non-diabetics $(\mathrm{p}=$ $0.05)$ with a male:female ratio of $77: 20(3.9: 1)$ and $77: 10(7.7: 1)$, respectively $(p=0.09)$. The mean body mass Index was $26.5 \pm 3.5$ for diabetics and $25.2 \pm 4.2$ for non-diabetics $(\mathrm{p}=0.07)$. Heart failure developed in 55 of the $97(57 \%)$ diabetics and 38 of the $87(43 \%)$ non-diabetics $(\mathrm{p}=0.05)$. The mean peak serum creatinine phosphokinase was higher in the diabetics $(1,607 \pm 1,431 \mathrm{IU} / \mathrm{l})$ than nondiabetics $(1,289 \pm 1,052 \mathrm{IU} / \mathrm{l} ; \mathrm{p}=0.04)$. Diabetic patients stayed longer than non-diabetics in the hospital, $11.6 \pm 2$ versus $9.9 \pm 4.8$ days $(p=0.03)$. Aspirin was given to 175 patients $(95 \%)$, beta blockers to $80(44 \%)$ and ACE inhibitors to 108 (59\%). As shown in table 1, no significant difference was observed in the use of aspirin and beta-blockers between diabetics and non-diabetics but ACE 
Table 1. Comparison between diabetics and non-diabetics in the use of secondary prevention measures

\begin{tabular}{|c|c|c|c|c|c|}
\hline \multirow[t]{2}{*}{ Variables } & \multicolumn{2}{|c|}{$\begin{array}{l}\text { Diabetics } \\
(n=97)\end{array}$} & \multicolumn{2}{|c|}{$\begin{array}{l}\text { Non-diabetics } \\
(\mathrm{n}=87)\end{array}$} & \multirow[t]{2}{*}{$\mathrm{p}$ value } \\
\hline & $\mathrm{n}$ & $\%$ & $\mathrm{n}$ & $\%$ & \\
\hline Aspirin & 94 & 97 & 82 & 94 & NS \\
\hline Beta-blockers & 42 & 43 & 38 & 44 & NS \\
\hline ACE inhibitors & 65 & 67 & 44 & 51 & $\mathrm{~S}$ \\
\hline
\end{tabular}

$\mathrm{S}=$ Statistically significant, $\mathrm{p}<0.05$. inhibitors were used more by diabetics than non-diabetics on discharge. Seven of the 97 (7.2\%) diabetic patients and 2 of the 87 $(2.3 \%)$ non-diabetics $(p=0.06)$ died. Three of the $80(3.8 \%)$ patients who were taking betablockers also died versus 77 of $80(96 \%)$ who were alive $(p=0.05)$.

\section{Discussion}

Diabetic patients were older than non-diabetics and had a higher ratio of females, which is similar to what has been reported by others [13-15]. The incidence of heart failure in diabetics presenting with acute MI was higher than in non-diabetics as they lacked recovery in wall motion score index and had a larger infarct size [16-18], an observation that is consistent with our findings. There was no difference between diabetics and non-diabetics in the use of aspirin and beta-blockers but ACE inhibitors tended to be used more by diabetics, which could be related to their higher incidence of heart failure. The use of ACE inhibitors in the early treatment of patients with MI and left ventricular dysfunction had been shown to improve ventricular ejection fraction, retard left ventricular dilatation following extensive MI, and lower myocardial oxygen consumption [19-21]. There is an underutilization of beta-blockers worldwide $[7,8,22]$. Only $44 \%$ of our patients were using beta-blockers on discharge with no significant difference between diabetics and non-diabetics.

Physicians have been reluctant to treat diabetics with beta-blockers because of the risk of worsening diabetes or of masking hypoglycaemic symptoms. Although it is true that blood glucose concentration may increase with the use of some beta-blockers [23], many studies have confirmed the benefits of betablockers in patients with diabetes mellitus $[24,25]$. Another reason for the underutilizaton of beta-blockers in diabetics could be the higher incidence of heart failure and the fear of worsening their heart failure condition. Chadda et al. [26] and others [22, 27, 28] have reported that patients can benefit from betablockers regardless of their ejection fraction. Many studies have shown that the use of betablockers after MI reduces mortality rate [23, 27, 29]. The use of beta-blockers has been shown to be an independent predictor of a 1year cardiac survival following hospital discharge for all diabetics [2]. Evidence supports the benefit of propranolol, timolol, metoprolol and atenolol in reducing mortality rate after MI [6, 27, 30, 31]. 


\section{Conclusion}

There is underutilization of beta-blockers in both diabetics and non-diabetics, not only in our hospital but also in others $[7,8]$ despite the substantial benefits and generally low treatment cost. Concern that side effects af- fect the usefulness of beta-blockers has to be tempered by the low yearly withdrawal from beta-blockers in long-term trials [27] and physicians should be encouraged to use betablockers as secondary prevention measures after MI.

\section{References}

1 Zuanetti G, Latini R, Maggioni AP, Santoro L, Franzosi MG: Influence of diabetes on mortality in acute myocardial infarction: Data from the GISSI-2 study. J Am Coll Cardiol 1993;22:1788-1794.

2 Kjekshus J, Gilpin E, Cali G, Blackey AR, Henning H, Ross J Jr: Diabetic patients and beta-blockers after acute myocardial infarction. Eur Heart J 1990;11:43-50.

3 Yusuf S, Peto R, Lewis J, Collins R, Sleight P: Beta-blockade during and after myocardial infarction: An overview of the randomized trials. Prog Cardiovasc Dis 1985;27:335371.

4 Beta-Blocker Heart Attack Study Group: The Beta-Blocker Heart Attack Trial. JAMA 1981;246:20732074.

5 The Norwegian Multicenter Study Group: Timolol-induced reduction in mortality and reinfarction in patients surviving acute myocardial infarction. N Engl J Med 1981;304: 801-807.

6 Hjalmarson A, Elmfeldt D, Herlitz J, Holmberg S, Malek I, Nyberg G, Ryden L, Swedberg K, Vedin A, Waggstein F, Waldenstrom A, Waldenstrom $\mathrm{J}$, Wedel $\mathrm{H}$, Wolhelmsen L, Wilhelmsson C: Effect on mortality of metoprolol in acute myocardial infarction: A double-blind randomized trial. Lancet 1981;ii:823827.
7 Ellerbeck EF, Jencks SF, Radford MJ, Kresowick TF, Craig AS, Gold JA, Krumholz HM, Vogel RA: Quality of care for Medicare patients with acute myocardial infarction: A four-state pilot study from the Cooperative Cardiovascular Project. JAMA 1995;273:1509_ 1514.

8 Brand Da, Newcomer LN, Freiburger A, Tian H: Cardiologists' practice compared with practice guidelines: Use of beta-blockers after acute myocardial infarction. J Am Coll Cardiol 1995;26:1432-1436.

9 Chowdhury TA, Lasker SS, Dyer $\mathrm{PH}$ : Comparison of secondary prevention measures after myocardial infarction in subjects with and without diabetes mellitus. J Intern Med 1999;245:565-570.

10 Mogensen CE: Preventing end-stage renal disease. Diabet Med 1998; 15(suppl 4):S51-S56.

11 Winters KJ, Eisenberg PR: Ischemic heart disease; in Ewald GA, McKenzie CR: The Washington Manual, ed 28. Boston, Little Brown, 1995, pp 94-97.

12 Diabetes mellitus: Report of a WHO Study Group. Tech Rep Ser 1985; 727:1-113.

13 Mak KH, Moliterno DJ, Granger CB, Miller DP, White HD, Wilcox RG, Califf RM, Topol EJ: Influence of diabetes mellitus on the clinical outcome in the thrombolytic era of acute myocardial infarction: GUSTO-I Invesigators. Global utilization of streptokinase and tissue plasminogen activator for occluded arteries. J Am Coll Cardiol 1997;30: 171-179.
14 Woodfield SL, Lundergan CF, Reiner JS, Greenhouse SW, Thompson MA, Rohrbeck SC, Deychak Y, Simoons ML, Califf RM, Topol EJ, Ross AM: Angiographic findings and outcome in diabetic patients treated with thrombolytic therapy for acute myocardial infarction: The GUSTO-I experience. J Am Coll Cardiol 1996;28:1661-1669.

15 Kip KE, Faxon DP, Detre KM, Yeh $\mathrm{W}$, et al: Coronary angioplasty in diabetic patients: The National Heart, Lung, and Blood Institute Percutaneous Transluminal Coronary Angioplasty Registry. Circulation 1996;94:1818-1825.

16 Tong N, Li H, Liang J: Comparative analysis of clinical features of acute myocardial infarction in diabetics and non-diabetic patients. Hua His I Ko Ta Hsueh Hsueh Pao 1996;27: 314-316.

17 Mahagoub MA, Abd-Elfattah AS: Diabetes mellitus and cardiac function. Mol Cell Biochem 1998;180: 59-64.

18 Azzarelli A, Dini FL, Cristofani R, Giaconi A, Rossi AM, Volterrani C, Lunardi M, Bernardi D: Ventricular function in the elderly: Echocardiography study. Coron Artery Dis 1995; 6:629-634.

19 Sharpe N: Studies of left ventricular dysfunction following myocardial infarction. Herz 1991; 16(special issue 1):272-277.

20 Mortarino G, Ghiringhelli S, Onofri M, Trudu A, Corda G, Lepori G: Mechanocardiographic effects of ACE-inhibitors. Acta Cardiol 1990; 45:537-546. 
21 Ertl G, Gaudron P, Eilles C: Modification of hemodynamics by angiotensin converting enzyme inhibitors in heart failure. Herz 1990;15:158163.

22 Gottlieb S, McCarter R, Vogel R Effect of beta-blockade on mortality among high risk and low risk patients after myocardial infarction. N Engl J Med 1998;339:489-497.

23 Giugliano D, Acampora R, Marfella $\mathrm{R}$, De Rosa H, Ziccardi P, Ragone $\mathrm{R}$, De Angelis L, d'Onfrio F: Metabolic and cardiovascular effects of carvedilol and atenolol in non-insulin-dependent diabetes mellitus and hypertension: A randomized, controlled trial. Ann Intern Med 1997; 126:955-959.
24 Gundersen T, Kjekshus J: Timolol treatment after myocardial infarction in diabetic patients. Diabetes Care 1983;6:285-290.

25 Malmberg K, Herlitz J, Hjalmarson A, Ryden L: Effect of metoprolol on mortality and late infarction in diabetics with suspected acute myocardial infarction: Retrospective data from two large studies. Eur Heart J 1989;10:423-428.

26 Chadda K, Goldstein S, Byington R Curb JD: Effect of propranolol after myocardial infarction in patients with congestive heart failure. Circulation 1986;73:503-510.

27 Freemantle N, Cleland J, Young P, Mason J, et al: Beta-blockade after myocardial infarction: Systematic review and meta regression analysis. BMJ 1998;318:1730-1737.
28 Cleland JGF, Freemantle N, McGowan J, Clark A: The evidence for beta-blockers in heart failure. BMJ 1999;318:824-825.

29 Beta-Blocker Pooling Project Research Group: The Beta-Blocker Pooling Project (BBPP): Subgroup findings from randomized trials in post-infarction patients. Eur Heart $\mathbf{J}$ 1988;9:8-16.

30 Randomized trial of intravenous atenolol among 16,027 cases of suspected acute myocardial infarction: ISIS-1, First International Study of Infarct Survival Collaborative Group, Lancet 1986;ii:57-66.

31 Reduction of infarct size with early use of timolol in acute myocardial infarction. N Engl J Med 1984;310: 9-11. 